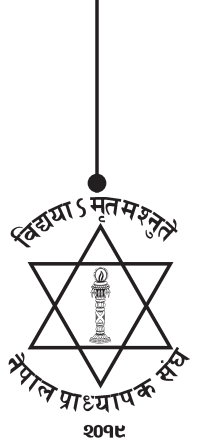

NJ: NUTA

\title{
Value Added Tax in Nepalese Context
}

\section{Dilnath Dangal}

PhD Scholar in Economics, Faculty of Humanities and Social Sciences

Lecturer, Ratna Rajya Laxmi Campus, Kathmandu, Tribhuvan University

Email for correspondence: dangaldilnath@gmail.com

\begin{abstract}
A value added tax (VAT) is a tax not on the total value of the commodity being sold, but on the value added by the last trader. Developing countries are engaging in the study of VAT more seriously as it is the source of tax revenue which has high tax potential yield among the existing tax systems. In this situation, this paper intended to assess practices of VAT and VAT administration as well as its contribution on GDP in Nepalese context. More so, the study collected secondary data which are analyzed based on descriptive/comparative methods. The study found that, sales tax has been replaced by VAT since 1997 in Nepal. Before that sales tax played a vital role to collect revenue and resources mobilization. Department of VAT and its field offices were/are responsible for administering VAT functions that was/ is not yet attractive and efficient. However, data shows that collecting VAT is in increasing order. In Fiscal Year 2014/15 it came to NRs. 11516 crore which was 5.42 percent of GDP, 29.60 percent of total revenue and 48.14 percent of indirect tax revenue. And the contribution of VAT as percent of GDP remained at average of 4.04 percent during the study period (2002/2003 to 2014/2015).
\end{abstract}

Key words: Value added tax (VAT), VAT administration, developing countries, tax system and revenue.

\section{Introduction}

Value added tax (VAT) approach was first recommended by William von Simens in 1919 in Germany replaced. However, VAT approach had already been discussed in early 1918 in Germany. Simens in 1919 in Germany to replaced the multi stage turnover tax in order to avoid the undesirable particularly cascading and vertical integration of the later tax (Adhikari, 2011). The VAT proposal was seriously considered by the then German government but as the tax was new and through to be complicated. It decided to reduce the rate of an improved from the turnover tax in the literature. The improvement consisted in the subtraction of previous outlays from taxable sales with the result that the tax base of each firm would be reduced to the value which it added to the product. In fact, in the history of taxation, value VAT is regarded as latest and the emerging tax system.

VAT is also known as goods and services tax, single business tax, or turnover tax in some countries, applies the equivalent of a sales tax to every operation that creates value. For an example, sheet steel is imported by a machine manufacturer. That manufacturer will pay the VAT on the purchase 
price, remitting that amount to the government. The manufacturer will then transform the steel into a machine, selling the machine for a higher price to a wholesale distributor. The manufacturer will collect the VAT on the higher price, but will remit to the government only the excess related to the value added (the price over the cost of the sheet steel). The wholesale distributor will then continue the process, charging the retail distributor the VAT on the entire price to the retailer, but remitting only the amount related to the distribution mark-up to the government. The last VAT amount is paid by the eventual retail customer who cannot recover any of the previously paid VAT. For a VAT and sales tax of identical rates, the total tax paid is the same, but it is paid at differing points in the process.

\section{Global Perspectives}

A study on VAT in developing countries was undertaken by the International Monetary Fund (IMF) staffs at the time when the introduction of VAT was gaining momentum in developed as well as in developing countries. The study examines the applicability of VAT in seven developing countries which have adopted VAT, considering the fact that many uncertainties arise in the introduction of any major new tax, especially regarding a system in which developing countries have very limited experience (Casanegra, Michele, \& George, 1973). According to the study, the most important feature of VAT in developing countries is its conceptual basis such as taxable base, exemptions, treatment of small traders. Problems of VAT implementation in developing countries are also great. In fact, the feasibility of VAT in developing countries depends largely upon the ability of those countries to administer it. The administrative efficiency is also influenced by the structure of VAT employed and the country's social and economic environment. The problems should also be viewed from the angle of taxpayers compliance, as the cost of doing business tends to increase with VAT because of the need to adopt new accounting procedures. The study shows that VAT produces between 10 to 30 percent of government revenues of the seven developing countries covered by the study and the VAT revenue in these countries is expected to increase at a faster rate than the rate of the growth of the economy (Casanegra, Michele, \& George, 1973).

Shende (2002) stated that the effectiveness of the VAT system can be determined by computing the 'VAT productivity,' a measure that focuses on VAT revenue as a percent of gross domestic product (GDP) divided by the VAT rate. It is also possible to estimate the amount of various types of income from national income accounts and other data sources. This information allows policy makers to estimate the potential tax revenue from different tax instruments assuming different tax compliance rates. In all these instances, the usefulness and reliability of these estimates are, of course, dependent on the quality of the underlying data. Part of the variation in aggregate tax revenues among countries can be explained by different demands and tastes for government services. The demand for government services tend to increase with per capita income. Countries, and presumably the residents of countries, may also have different views on such important questions as the public versus private provision of education, health, and retirement benefits, and the size and quality of government provisions of defense, transportation and other services. These are primarily political questions to which economic advisors may have little to contribute. As taxes are the primary vehicle to fund government services, higher taxes are required to fund higher level of government services.

Guerard (1973) evaluated the Brazilian VAT against the background provided by two broader issues: one as a case study of the VAT in a developing country and the other as an illustration of the 
problem posed by inter-state tax co-ordination in a special setting of a federation caused by huge regional disparities. The Brazilian States adopted a broad-based single-rated (i.e. $15 \%$ ) VAT in 1976 in the place of existing heterogeneous turnover taxes aiming to secure a greater degree of tax coordination among the states of the federation. The VAT was based on modified origin principle, and it extended to retail level with minimum exemptions. The administration of the tax did not appear burdensome. Soup (1969), explained in his Public Finance Book, VAT as the latest and probably the final stage in a historical development of general sales tax, imposed on the values added by business firms. He explained VAT on the difference between sales proceeds and the cost of material purchased from other firms which is the tax base of a VAT. The firm further added value by proceeding or handling these purchased items with its labor forces, machinery building and capital goods. VAT had eliminated the uneven impact of turnover tax and the manufactures and whole- sales taxes. Considering both closed and open economy he classified three types of VAT (i.e. gross product type of VAT, income type of VAT and capital exemption type of VAT [wage types of VAT \& consumption type of VAT]). After distinguishing the type of VAT he stated the superiority of consumption type of VAT. In over all, he reflected that VAT is very fast growing tax in the field of taxation. It is revenue productive and neutral but somewhat regressive and complex, hence, challenging for the developing countries (Soup, 1969).

\section{Research Objectives}

- To examine historical development of VAT in Nepal.

- To assess administrative capacity and function of VAT system in Nepal.

- To assess contribution of VAT on Nepalese Gross Domestic Product.

\section{Research Method}

The study is library based. Required data/information was collected from secondary sources. While analyzing quantitative/time series data (from 2002/2003 to 2014/2015) and conceptual/empirical information, comparative/descriptive methods are applied (Creswell, 2009). The secondary data and information used in the study are collected from economic survey of ministry of finance, unpublished thesis/dissertation as well as books and journal articles. The data are analyzed by use of table and figure.

\section{Development of VAT in Nepal}

In Nepal, VAT was introduced on 16 November 1997 (Shrama, 2008). This tax was levied in place of the manufacturing level, sales tax, hotel tax, contract tax and entertainment tax. However, it could not be implemented fully until the Fiscal Year 1998/99 due to the political instability and strong opposition from the business community. VAT replaces the old sales tax, the contract tax, the hotel tax and entertainment tax. It has been designed to collect the same revenue as the four taxes it replaced. Since the collection of both custom duties and income tax depends to a great extent upon the effectiveness of VAT, it is expected to help enhance revenue collection. The VAT is broad based tax as it covers the value added to each commodity by a firm during all stages of production and distribution. It is a modern tax system to improve the collection of taxes, to increase efficiency and to minimize tax evasion. It is also regarded as the backbone of income tax system in Nepal (Shrama, 2008, p.3).

Before the adoption of VAT in Nepal, the contribution of sales tax was not significant as compared to custom duties and VAT revenue of recent years. Revenue from VAT remained low for 
the first three fiscal years VAT implementation because of poor registration, implementation, lack of adequate preparation of administration, lack of adequate knowledge to tax payers. But its share to indirect tax has been gradually increasing now to then. VAT has been imposed on the value added in each and every economic activity whether that is related to production or consumption as it is charged to value addition done to prepare the final product. Ultimate resting-place of this tax is final consumption so that consumers are the sole taxpayers of the VAT. Business people only collect the VAT as a mediator so that don't bear its burden. In conclusion, VAT should be the most essential choice for the developing countries as an ingredient of their tax reforms because it is the most improved from of sales tax and revenue enhancement and economic efficiency. It is an important instrument for the mobilization of internal resources. There is tremendous scope for increase in its contribution in coming days. VAT is an improved form of sales tax. It is not a genuinely new form of taxation but merely a sales tax administered in different form. Under VAT system, consumer knows the amount they are paying in form of VAT. VAT is more transparent and account based tax system. Thus, tax reform and adoption of a VAT is integral part of whole tax system in present situation.

VAT is considered as the mostly growing trend in the field of taxation: Discussing the merits of VAT, the reason for its growing attraction in the world are: (i) VAT is based on the most modern theories (ii) It is more informative and sustain (iv) increment of taxpayers are also advanced . (v) It is less tedious (vi) it is free from cascading effect due to the input tax credit (vii) it is effective to control price raise and reduce tax evasion (Silwal, 1998). Discussing the development of tax in Nepal the author focuses the problems of Nepalese sales taxes such as administrative in efficiencies, very large number of small taxpayers with no record keeping and issuing the invoices and sales tax concentrated only on import manufacturing level. Considering modern context and fulfilling the resource scarcity, it the time of introducing VAT in Nepal. VAT is a multiple sales tax, which has grown on a hybrid of turnover tax and detail level sales tax. It is similar to turnover tax in the sense that both these taxes are imposed at each stage in the production and distribution process. VAT; however differ from the turnover tax as the later is imposed on total value at each stage while the former is imposed only on value added at that stage. VAT is similar to the retails stage sales tax because the tax base of VAT (consumption type VAT) and of the retails level sales tax on consumer goods and services are identical. VAT, however varies from retails level sales tax in the sense that the former is imposed at each stage of production and distribution while the latter is imposed only of one stage, which is the final stage. Theoretically, VAT is broad-based as it covers the value added to each commodity by form during all stages of production and distribution. There is the presumption that VAT is shifted forward completely to the consumers (Khdka, 2001, p. 1).

Nepal Chamber of Commerce had organized a nationwide discussion program on VAT. The discussions program summarized that government machinery is not capable for implementing a VAT. VAT will hamper genuine trade and as a consequence, illegal trade will prosper. Rise in the prices of domestic products will make them less competitive. Import and re-export of imported goods will get a negative impact leading to decline in government revenue. VAT will inhabit the growth of newly developing trade and industrial activities in the country. The modern account keeping system required by the VAT is difficult to keep. This will raise the costs of doing business (Nepal Chamber of Commerce, [NCOC], 1997). There will a sharp price rise if a VAT is introduced; consumers will be badly affected 
due to price raise. Nepalese markets in boarder area will dry up due to VAT. It is concluded that it is not possible to implement a VAT in Nepal and if implemented, it will have adverse effect on the economy (Shrama, 2008, p.25).

\section{VAT Administration}

The VAT organization was structured along functional lines. Sections and sub-sections were created for each function. Large taxpayers, tax refund, taxpayer service, tax audit and investigation, internal monitoring, collection and registrations were important sections of VAT administration (Dhakal, 2004). The duties of each unit and the job description of each position in the organization were spelt out clearly. Under the functional structure, a tax officer was made responsible to carry out a specific job like registration, collection, refund or audit. The inherent idea is to allow any tax officer to meet his/her career aspirations and interests and to nurture specialists in the area of tax administration. Evolution of a corruption-free system was considered as a precondition for an efficient and transparent tax administration. Since the bulk of the tax come from a few taxpayers that pay high taxes, a large taxpayer unit was created in Department of VAT in order to treat them in the way that best suited their needs.

Similarly, an internal monitoring unit was also created in order to examine whether or not all tasks assigned to the VAT administration were carried out in the desired fashion. To this end, personnel from the internal monitoring section analyzed the performance of various sections in the department and field offices. They fixed targets for frequency of visits, and the issues which must be looked into in each major area of work. They prepared a checklist that covered all major functions of the tax administration based on advice, from the management of the VAT Department. The unit visited VAT offices periodically and extended advice to VAT forces in case of errors, and also submitted reports to the higher functionaries outlining their findings. They also conducted follow up their reports and dealt with any special issues that cropped up from time to time. Since about 60 percent of total revenue was generated from imports by the customs offices, it was necessary to conduct internal monitoring of imports. However, this proved ineffective since it was restricted in scope.

The idea concerning internal monitoring was agreed to in principle, but was not implemented owing to a lack of interest on the part of the customs administration. Meanwhile, a new personal administration system was introduced for the administration of VAT. Under this system, the number of gazetted officers was raised while the numbers of non-gazetted clerical personnel was cut down. The Department of VAT and its field offices were responsible for administering VAT and excise duty. The Department of VAT was responsible for setting operational guidelines, program development and evaluation, designing forms and instructional material, compiling statistics and performing analysis, and drawing up budgets allocating resources. Offices under it were responsible for collecting VAT and excise duty. However, VAT administration was not attractive. In fact, even the staffs were keen to be transferred to customs. Similarly, those posted at the Ministry of Finance or at the customs or other tax offices did not want to be transferred to the VAT administration.

\section{Ratio of VAT to GDP}

Most of the developing countries are now engaged in the study of VAT very seriously and most of the economists of all countries have realized that the VAT only is the source of tax revenue which has very high tax potential yield among the existing tax systems. It will not be on exception 
for Nepal. VAT is said to be consumption tax by when the taxable good and services are consumed will ultimately pay the tax. If any goods become spoiled before consuming, it will not liable to tax. Nepal government had planned to introduce VAT on Mangshir 1, 2054 (November, 1997/098). VAT is the replacement of sale tax making tax burden not on total value but on the value added to the main objective not to effect in the increase price (Dangol, 2002, p.2). There are several reasons to introduce VAT in Nepal. They are: (Thapa, 2002).

- To introduce VAT in order to broaden the base of domestic trade taxes.

- To make tax system neutral and efficient.

- To increase revenue mobilization by broadening the tax.

- To minimize the cost of taxation.

- To establish a transaction based transparent tax system and for economic development.

The feature of tax are classified under; input tax credit (tax paid on earlier stages), neutrality (VAT does not offer unnecessary burden of tax in any sector), compulsory invoice system (for its good operation) and wide tax coverage (covering from importing and producing to retailing stage, products, services, and others) for minimizing possibility of tax evasion (Silwal,1998). Sales tax has been replaced by VAT since 1997 in Nepal. Before introducing VAT, sales tax played a vital role to collect revenue and resources mobilization. After introducing VAT, it has increased revenue mobilization by broadening the tax and also contributing to national GDP (see in table 1).

Table 1. Contribution of VAT as Percentage to GDP

(As Percent of Indirect Taxes, Total Revenue and GDP)

\begin{tabular}{lccccc}
\hline Fiscal Year & $\begin{array}{c}\text { Revenue from VAT } \\
\text { (Rs in Crore) }\end{array}$ & $\begin{array}{c}\text { As Percent of } \\
\text { Indirect Taxes }\end{array}$ & $\begin{array}{c}\text { As Percent } \\
\text { of Total Tax } \\
\text { Revenue }\end{array}$ & $\begin{array}{c}\text { As Percent } \\
\text { of Total } \\
\text { Revenue }\end{array}$ & $\begin{array}{c}\text { As Percent } \\
\text { of GDP }\end{array}$ \\
\hline $2002 / 03$ & 1346 & 41.45 & 30.94 & 23.55 & 2.73 \\
$2003 / 04$ & 1448 & 39.93 & 29.90 & 23.14 & 2.70 \\
$2004 / 05$ & 1889 & 46.04 & 34.71 & 26.82 & 3.21 \\
$2005 / 06$ & 2161 & 49.72 & 37.27 & 29.67 & 3.30 \\
$2006 / 07$ & 2610 & 50.05 & 36.34 & 29.52 & 3.59 \\
$2007 / 08$ & 2982 & 48.04 & 34.33 & 27.28 & 3.66 \\
$2008 / 09$ & 3972 & 48.00 & 33.33 & 27.28 & 4.02 \\
$2009 / 10$ & 5509 & 48.02 & 34.65 & 30.61 & 4.62 \\
$2010 / 11$ & 6187 & 49.77 & 35.12 & 30.45 & 4.50 \\
$2011 / 12$ & 7093 & 49.05 & 35.12 & 30.24 & 4.62 \\
$2012 / 13$ & 8351 & 47.04 & 32.31 & 28.28 & 4.91 \\
$2013 / 14$ & 10110 & 47.03 & 32.70 & 28.62 & 5.21 \\
$2014 / 15$ & 11516 & 48.14 & 33.08 & 29.60 & 5.42 \\
\hline Average & $\mathbf{5 0 1 3}$ & $\mathbf{4 7 . 0 9}$ & $\mathbf{3 3 . 8 3}$ & $\mathbf{2 8 . 0 8}$ & $\mathbf{4 . 0 4}$ \\
\hline
\end{tabular}

(Ministry of Finance, 2015).

The above table reflects the contribution of VAT on GDP, total tax revenue and indirect tax revenue. The contribution of VAT in Nepal has fluctuated during the study periods. Data indicates that contribution of VAT to indirect taxes has fluctuated between nearly 50.05 percent to 39.93 percent. Total VAT was Rs. 1346 crore in the FY 2002/03. The contribution of VAT as percent of GDP remained 
at an average of 4.04 percent during the study period. The trend of VAT to the indirect taxes also can be seen in figure 1 .

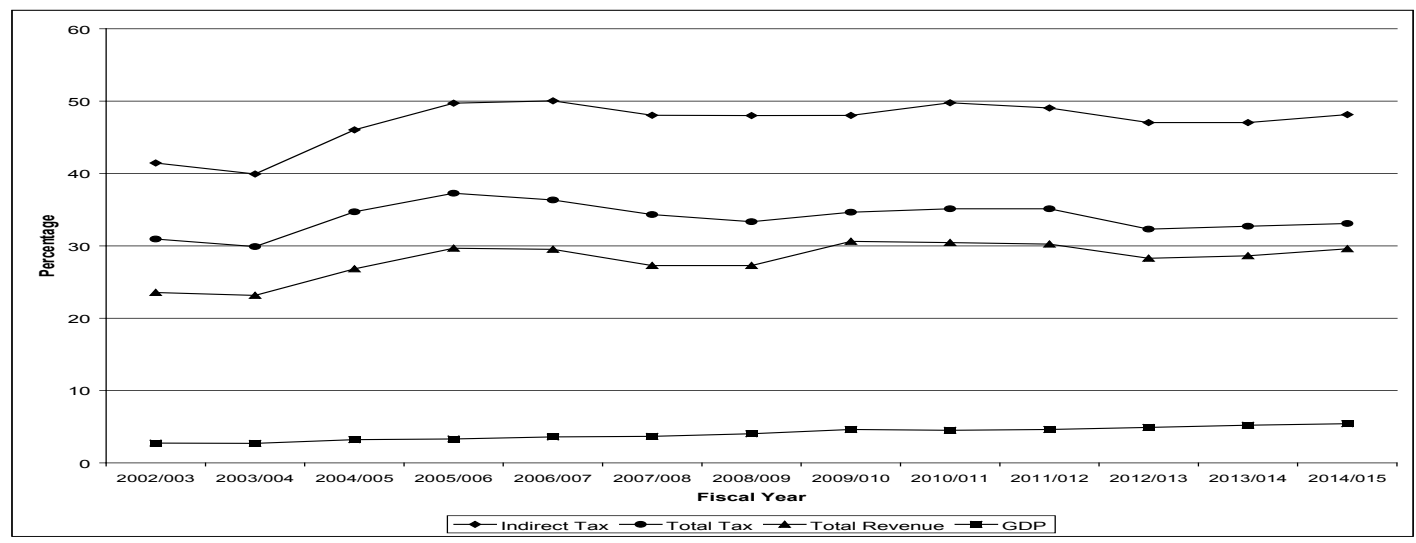

Figure 1. Trend of VAT to the Indirect Taxes, Total Revenue and GDP in Percentage (Ministry of Finance, 2015).

The above figure shows, trend analysis of VAT to the indirect taxes. During the study period it is found increasing order and in FY 2014/15 it came to Rs. 11516 crore which was 5.42 percent of GDP, 29.60 percent of total revenue and 48.14 percent of indirect tax revenue. While transferring goods from productive area to market government provided identity card for tax payer. Business man used to get permission to entry in city after enquiry by tax collecting officer. Before entering in city they should pay entry fee. Without money who tried to enter in the city, they used to pay four times of tariff. Business man who hide actual price of gold, there was a system for them to go government fund more than actual price. In the same manner, the contributions of VAT on GDP in south Asian countries are as follows; Bangladesh 5.5, Bhutan 2.7, India 0.7, Maldives, Pakistan 3.7 and Shrilanka 3.3 percent.

\section{Conclusion}

Value Added Tax (VAT) is that indirect tax which is imposed only on the value added at each stage of production and distribution of goods and services. It is the imposing of tax on sales of goods and services minus the purchase of goods. VAT as its name implies, is a tax in the value added to a commodity or service (i.e. except export and government service). Its special characteristics being that it falls on the value added at each stage from the stage of production to retail stage. It means that the value added tax is imposed on the value that business firm adds to the goods and services that purchased from other firms. It also adds value by processing or handling these purchased goods with its own labour force or machinery, building or other firms. However, value added tax belongs to the family of sales tax. A general sales tax is a tax on sales transactions but it has been applied at only one stage of the business activities. Discussing the incidence of VAT in an open economy if demand is not inelastic, there remain the possibilities of exporting some of tax to non-resident factor owner. 


\section{References}

Adhikari, C. M. (2011). Tax laws of Nepal. Kathmandu: Pairabi Prakashan.

Casanegra, M., Michele, G., \& George, E. L. (1973). The value added tax in developing countries. IMF Working Paper No. 2.

Creswell, J. W. (2009). Research Design: Qualitative, quantitative and Mix Methods Approaches (3rd ed.). University of Nebraska-Lincoln: Sage Publication.

Dangol, M. L. (2002). Resource mobilization through value added tax (VAT) in Nepal, [Unpublished MBS. Thesis]. Submitted in Shankar Dev Campus, Kathmandu.

Dhakal, K. D. (2004). Income tax administration in Nepal: Areas for reform, [Unpublished Doctoral Dissertation]. Submitted to Central Department of Management, Kathmandu.

Guerard, P. (1973). Impact of VAT in Brazilian economy, [Unpublished Doctoral Dissertation]. Submitted to Columbia University, New York.

Khadka, R. B. (2001). Income Taxation in Nepal. Retrospect and Prospect. Kathmandu: Ratna Pustak Bhandar.

Ministry of Finance (2013). Economic Survey. Kathmandu: Ministry of Finance.

Ministry of Finance (2015). Revenue Advisory Committee Report. Kathmandu: Ministry of Finance.

Nepal Chamber of Commerce (NCC). Chamber Patrika. Author.

Nepal Chamber of Commerce. (1997). Impact of New Tax Policy in Export in Nepal.

Sharma, R. L. (2008). Issues and practice of VAT in Nepal, [Unpublished MBS. Thesis]. Submitted to Central Department of Management, Kathmandu.

Shende, S. N. (2002). Informal Economy Special Taxpayer Regime for Small and Micro Businesses. Design and Implementation. A Paper presented at the Third Regional Training Workshop on Taxation (United Nations and Center for Inter-American Tax Administrations (CIAT): Brasilia).

Shoup, C. S. (1969). Public Finance. London : Widenfeld and nicolson Ltd.

Silwal, N. (1998). Value added tax: Its problems and prospects in Nepal. Rajashwa, Nepal Journal of Public Finance and Development, 2. Kathmandu.

Thapa, G. B. (2002). Tax System and Its Reform. Business Age, 4. 